\title{
COMMENTARY
}

\section{Influenza and bacterial pneumonia - constant companions}

\author{
Richard G Wunderink* \\ See related review by van der Sluijs et al., http://ccforum.com/content/14/2/219
}

\begin{abstract}
Sequential or concomitant influenza and bacterial pneumonia are two common syndromes seen in community-acquired pneumonia. Inadequacies of diagnostic testing make separating simple pneumonia with either bacteria or influenza from concomitant or sequential influenza with both microorganisms difficult, although the novel 2009 H1N1 epidemic may improve the availability of molecular testing for viruses. Given the frequency of viral pneumonia and diagnostic limitations, empirical antivirals may be underutilized in community-acquired pneumonia. Thankfully, increasingly effective vaccines appear to disrupt this synergistic relationship.
\end{abstract}

In the previous issue of Critical Care, van der Sluijs and colleagues [1] reviewed the pathogenesis of influenza and bacterial pneumonia, particularly pneumococcal. They pointed out critical differences in pathogenesis between various combinations of influenza and bacterial pneumonia. Four potential syndromes are possible. The classic syndrome is bacterial pneumonia following an antecedent influenza infection [2]. Bacterial pneumonia without any antecedent viral infection has been associated with a slightly better prognosis. Increasingly, concomitant bacterial and influenza pneumonia have been described and, while less common, appear to have a worse prognosis than sequential infection. Important pathophysiologic differences between these syndromes are illustrated in this review. Unexplored in their review is viral pneumonia without complication by bacterial pneumonia. Primary influenza pneumonia without complication by bacterial pneumonia appears to be common in the 2009 H1N1 influenza epidemic.

*Correspondence: r-wunderink@northwestern.edu

Pulmonary and Critical Care, Northwestern University Feinberg School of Medicine, 676 North St. Clair Street, Suite 14-044, Chicago, IL 60611, USA
The difficulty with separating these syndromes is the inaccuracy of etiologic diagnosis for community-acquired pneumonia (CAP). The CDC (Centers for Disease Control and Prevention) has recognized this difficulty and conceded to report combined influenza and pneumonia deaths since prior to 1900 [3]. The cause of the majority of CAP cases remains undefined with the usual culture-based approach (mainly blood cultures and occasional sputum or more invasive respiratory cultures). One of the lasting effects of the 2009 novel H1N1 influenza epidemic may be the increasing sophistication and availability of molecular diagnostic tests for influenza (and other respiratory viruses). During the peak of the epidemic, reverse transcriptase-polymerase chain reaction (RT-PCR) for influenza was available in many large institutions within 8 to 12 hours of sampling. RT-PCR clearly is faster than culture and much more sensitive than the rapid influenza tests previously available. The trophism for the lower respiratory tract characteristic of the 2009 H1N1 influenza virus had diagnostic implications in addition to the pathophysiologic significance of higher incidence and severity of primary viral pneumonia with acute lung injury/acute respiratory distress syndrome [4]. The diagnostic issue was that patients occasionally had negative nasopharyngeal RT-PCR tests while lower respiratory tract samples were positive [5]. The frequency with which this occurs with other strains of influenza or other respiratory viruses is unknown.

One caveat of the data regarding concomitant CAP is that viral or atypical pathogen co-infection in these studies was often diagnosed only by serologic conversion. Sequential versus concomitant influenza and bacterial pneumonia cannot be distinguished in this way. Therefore, the differential effect on mortality and morbidity of concomitant versus sequential influenza and bacterial pneumonia remains somewhat unclear.

Unfortunately, molecular diagnosis of bacterial infection lags behind that of viral. The best routinely available diagnostic aids are the BinaxNOW urinary antigens (Inverness Medical International, Cranfield, UK) for both pneumococcus and Legionella pneumophila. The pneumococcal urinary antigen can increase the diagnosis of 
pneumococcal pneumonia by $10 \%$ to $30 \%$ in prospective studies. False-positives, often after a previous upper respiratory infection such as otitis media, limit its accuracy in children and HIV-positive patients. The Legionella urinary antigen is limited to one serogroup of L. pneumophila which is neither the most common strain nor serotype in certain areas of the world. In addition, the assay picked up only $50 \%$ of cases and had almost mutually exclusive results compared with a Legionella PCR assay on sputum.

Whole-blood PCR for bacterial pathogens is generating increasing interest. Recent studies of the pneumococcal lyt A gene have increased the number of patients diagnosed with pneumococcal disease, and quantitation appears to have additional prognostic significance [6]. Similar prognostic significance of quantitative PCR has been demonstrated for a meningococcal gene.

The result of diagnostic limitations is that most treatment for CAP remains empirical. Empirical antibiotics are the standard, but concern about delayed antivirals in the recent pandemic significantly increased the use of empirical antivirals as well. Clearly, this strategy makes the most sense for concomitant bacterial and influenza pneumonia. Given the limitations of etiologic diagnosis, the benefit of empirical antibiotics for occult bacterial pneumonia in patients with documented influenza is unclear. Conversely, empirical antivirals for culture- and urinary antigen-negative CAP patients may be rational since viruses may be the etiology in up to $15 \%$ of cases [7], with influenza being the most common viral pathogen. The incidence of primary influenza or concomitant influenza CAP is clearly as high as that of community-acquired methicillin-resistant $S$. aureus (CA-MRSA) [8] or Pseudomonas, for which empirical antibiotics in the appropriate settings have been recommended by guidelines [9].

The good news is that prevention of one appears to prevent death from the other. The decrease in positive influenza cultures and influenza-related deaths, particularly among children, starting 6 to 8 weeks after the first dose of the novel $2009 \mathrm{H} 1 \mathrm{~N} 1$ vaccine became available is impressive [10]. Conversely, the pediatric conjugate pneumococcal vaccine decreased invasive pneumococcal disease in infants as well as their adult caregivers [11], even during peak years of epidemic influenza. Hopefully, higher valent and adult conjugate vaccines will soon become available to disrupt this lethal relationship even further.

\section{Abbreviations}

CAP, community-acquired pneumonia; $P C R$, polymerase chain reaction; RT$P C R$, reverse transcriptase-polymerase chain reaction.

\section{Competing interests}

RGW is on the data safety monitoring committee for an adult conjugate pneumococcal vaccine (originally Wyeth [Madison, NJ, USA], now Pfizer Inc [New York, NY, USA]). In last 2 years, he has received a reimbursement of less than $\$ 5,000$ for time reviewing data and for meetings.

Published: 13 May 2010

\section{References}

1. van der Sluijs KF, van der Poll T, Lutter R, Juffermans NP, Schultz MJ: Bench-tobedside review: Bacterial pneumonia with influenza - pathogenesis and clinical implications. Crit Care 2010, 14:219.

2. Ampofo K, Bender J, Sheng X, Korgenski K, Daly J, Pavia AT, Byington CL: Seasonal invasive pneumococcal disease in children: role of preceding respiratory viral infection. Pediatrics 2008, 122:229-237.

3. Heron M, Hoyert DL, Murphy SL, Xu J, Kochanek KD, Tejada-Vera B: Deaths: final data for 2006. Natl Vital Stat Rep 2009, 57:1-134.

4. ANZIC Influenza Investigators, Webb SA, Pettilä V, Seppelt I, Bellomo R, Bailey M, Cooper DJ, Cretikos M, Davies AR, Finfer S, Harrigan PW, Hart GK, Howe B, Iredell JR, McArthur C, Mitchell I, Morrison S, Nichol AD, Paterson DL, Peake S, Richards B, Stephens D, Turner A, Yung M: Critical care services and 2009 H1N1 influenza in Australia and New Zealand. N Engl J Med 2009, 361:1925-1934.

5. Rello J, Rodríguez A, Ibañez P, Socias L, Cebrian J, Marques A, Guerrero J, Ruiz-Santana S, Marquez E, Del Nogal-Saez F, Alvarez-Lerma F, Martínez S, Ferrer M, Avellanas M, Granada R, Maraví-Poma E, Albert P, Sierra R, Vidaur L, Ortiz P, Prieto del Portillo I, Galván B, León-Gil C; H1N1 SEMICYUC Working Group: Intensive care adult patients with severe respiratory failure caused by Influenza A (H1N1)v in Spain. Crit Care 2009, 13:R148.

6. Rello J, Lisboa T, Lujan M, Gallego M, Kee C, Kay I, Lopez D, Waterer GW; DNANeumococo Study Group: Severity of pneumococcal pneumonia associated with genomic bacterial load. Chest 2009, 136:832-840.

7. Johnstone J, Majumdar SR, Fox JD, Marrie TJ: Viral infection in adults hospitalized with community-acquired pneumonia: prevalence, pathogens, and presentation. Chest 2008, 134:1141-1148.

8. Lobo $L$, Reed KD, Wunderink RG: Expanded clinical presentation of community-acquired MRSA pneumonia. Chest 2010 Feb 19. [Epub ahead of print].

9. Mandell LA, Wunderink RG, Anzueto A, Bartlett JG, Campbell GD, Dean NC, Dowell SF, File TM Jr., Musher DM, Niederman MS, Torres A, Whitney CG; Infectious Diseases Society of America; American Thoracic Society: Infectious Diseases Society of America/American Thoracic Society consensus guidelines on the management of community-acquired pneumonia in adults. Clin Infect Dis 2007, 44 Suppl 2:\$27-72.

10. Centers for Disease Control and Prevention - Seasonal Influenza (Flu) Weekly Report: Influenza Summary Update [http://www.cdc.gov/flu/ weekly/].

11. Whitney CG, Farley MM, Hadler J, Harrison LH, Bennett NM, Lynfield R, Reingold A, Cieslak PR, Pilishvili T, Jackson D, Facklam RR, Jorgensen JH, Schuchat A; Active Bacterial Core Surveillance of the Emerging Infections Program Network: Decline in invasive pneumococcal disease after the introduction of protein-polysaccharide conjugate vaccine. N Engl J Med 2003, 348:1737-1746.

\section{doi:10.1186/cc8974}

Cite this article as: Wunderink RG: Influenza and bacterial pneumonia constant companions. Critical Care 2010, 14:150. 